\title{
Analysis of the Protection of Input Subsidies Policy (Fertilizer and Seed) and Production Output in Rice Plant Agriculture in Indonesia
}

\author{
By: \\ Adi Poernomo \\ Faculty of Economics, Universitas Wijayakusuma Purwokerto \\ Email: ebotpurnama@gmail.com
}

\begin{abstract}
The background of this research was on policy issues of continuing increased subsidies for fertilizer and seed rice from year to year, which was also faced the problem of inefficient economic and government budget allocations, the price disparity between input and output and its derivatives result and also the creation of unreal competitiveness as a result of the use of subsidized inputs. This study aims to determine the "protection coefficient" of subsidized inputs (fertilizer and seeds) and output in agriculture rice plants in Indonesia. Policy Analysis Matrix (PAM) is used to analyze the impact of subsidies on rice crop farming system in Indonesia. The analysis result of the Policy Analysis Matrix (PAM), shows that (1) the rice farming system has the profit of market prices and social prices, (2) government policies are simultaneously protective to the production capability, (3) It has a competitive and a comparative advantage.
\end{abstract}

Keywords: Subsidies on Fertilizer and Rice Seeds, Protection Coefficient, The Policy Analysis Matrix.

\begin{abstract}
ABSTRAK
Latar belakang dari penelitian ini isu kebijakan peningkatan subsidi pupuk dan benih menghadapi masalah alokasi pemerintah dan ketidakefisienannya, perbedaan harga antara input dan output dan hasil turunannya dan juga penciptaan daya saing yang tidak nyata sebagai akibat dari penggunaan input bersubsidi. Penelitian ini bertujuan untuk menentukan "koefisien perlindungan" dari input bersubsidi (pupuk dan biji-bijian) dan output pada tanaman padi pertanian di Indonesia. Policy Analysis Matrix (PAM) digunakan untuk menganalisis dampak subsidi pada sistem pertanian tanaman padi di Indonesia. Hasil analisis Matriks Analisis Kebijakan (PAM), menunjukkan bahwa (1) sistem usahatani padi memiliki keuntungan harga pasar dan harga sosial, (2) kebijakan pemerintah secara simultan melindungi kemampuan produksi, (3) memiliki kompetitif dan keunggulan komparatif.
\end{abstract}

Kata Kunci: Subsidi Pupuk dan Benih Padi, Koefisien Perlindungan, Matriks Analisis Kebijakan.

\section{INTRODUCTION}

Agricultural input subsidies are a form of rural (traditional) agricultural development policy which is generally carried out as price subsidies that can be accessed by all rural farmers, or for all producers in certain categories. The fundamental reason for subsidies in agricultural development is focused on increasing agricultural productivity with the adoption of new technologies that are more attractive to smallholders (Susila, 2010).

Fertilizer subsidies that are very expensive will create demands on increasing the government budget because it will stimulate an increase in fertilizer consumption (Pearce, 2002), which is mostly due to inefficiency in its use or because of the limited knowledge of farmers about the benefits of 
inputs and their correct use, politics is also often the cause of pressure to increase the amount of subsidies, or to maintain the turbulence of rising input prices. Input subsidies should be able to help farmers implement the benefits of subsidies, and receive subsidies to buy and use inputs for their own needs and it must be understood that subsidies cannot be given continuously or to the extent that farmers must be able to get out of dependence on subsidies.

The development of subsidy realization of fertilizer and seed spending in 2010-2015 is presented in the table:

Table 1. Realized Budget Allocation for Fertilizer and Seed Subsidies (Billion Rupiah)

\begin{tabular}{ccccrcc}
\hline Year & $\begin{array}{c}\text { Fertilize } \\
\text { Subsidies }\end{array}$ & $\begin{array}{c}\text { Total } \\
\text { Subsidies (\%) }\end{array}$ & $\begin{array}{c}\text { Non Energy } \\
\text { Subsidies }\end{array}$ & $\begin{array}{c}\text { Seed } \\
\text { Subsidies }\end{array}$ & $\begin{array}{c}\text { Total } \\
\text { Subsidies (\%) }\end{array}$ & $\begin{array}{c}\text { Non Energy } \\
\text { Subsidies }\end{array}$ \\
\hline 2008 & $15.181,50$ & $5.51 \%$ & $29.04 \%$ & 985,20 & $0.36 \%$ & $1.88 \%$ \\
2009 & $18.329,00$ & $13.27 \%$ & $42.14 \%$ & $1.597,20$ & $1.16 \%$ & $3.67 \%$ \\
2010 & $18.410,90$ & $9.55 \%$ & $34.90 \%$ & $2.177,50$ & $1.13 \%$ & $4.13 \%$ \\
2011 & $16.344,60$ & $5.53 \%$ & $41.12 \%$ & 96,90 & $0.03 \%$ & $0.24 \%$ \\
2012 & $13.958,50$ & $4.03 \%$ & $34.95 \%$ & 60,30 & $0.02 \%$ & $0.15 \%$ \\
2013 & $17.932,70$ & $5.15 \%$ & $37.14 \%$ & $1.454,20$ & $0.42 \%$ & $3.01 \%$ \\
2014 & $21.048,80$ & $6.31 \%$ & $40.81 \%$ & $1.564,80$ & $0.47 \%$ & $3.03 \%$ \\
2015 & $35.703,10$ & $16,83 \%$ & $51,02 \%$ & 939,40 & $0,44 \%$ & $1,34 \%$ \\
\hline
\end{tabular}

Source: Financial Note of APBN 2015 and RAPBN 2016

The realization of the fertilizer subsidy budget allocation is channeled through fertilizerproducing state-owned enterprises, showing a fluctuating increase from 2008-2015, with the highest subsidy allocation occurring in fertilizer subsidies in 2015 valued at Rp35,70 trillion with a proportion of 51,02 percent of the total non-energy subsidies or 16,83 percent of the total subsidy allocation, this is the biggest subsidy allocation for the last eight years. In the period 2008-2015, in the seed subsidy post, in addition to accommodating price subsidies also included a budget for superior seed direct assistance (BLBU) and national seed reserves (CBN). The realization of the seed subsidy budget in that period was nominally very volatile with the largest value in 2010 amounting to Rp2,17 trillion. In 2011 and 2012, budget allocations declined sharply from 2010 because since 2011 seed subsidies only accommodated price subsidies. In 2013-2014 sharply increased in the range of Rp1,5 trillion while in 2015 again decreased to Rp939,4 billion. (NK RAPBN, 2016). This indicates certain strategic considerations in the allocation of seed subsidies during the period 2008 to 2015.

The description of the production capacity and agricultural productivity of rice plants in the period 2010 to 2014 can be seen in the table:

Table 2. Production, productivity and rice harvest area in 2010-2014

\begin{tabular}{|c|c|c|c|c|c|c|}
\hline Rice Commodity & 2010 & 2011 & 2012 & 2013 & 2014 & Growth (\%) \\
\hline \multicolumn{7}{|c|}{ Production (in 1000 ton) } \\
\hline Java & $36,375.00$ & $34,405.00$ & $36,527.00$ & $37,493.00$ & $36,659.00$ & $0.29 \%$ \\
\hline Outside Java & $30,094.00$ & $31,352.00$ & $32,529.00$ & $33,787.00$ & $34,173.00$ & $3.24 \%$ \\
\hline Indonesia & $66,469.00$ & $65,757.00$ & $69,056.00$ & $71,280.00$ & $70,832.00$ & $1.63 \%$ \\
\hline \multicolumn{7}{|c|}{ Productivity (ku/ha) } \\
\hline Java & 57.21 & 55.81 & 59.05 & 57.98 & 57.28 & $0.08 \%$ \\
\hline Outside Java & 43.65 & 44.54 & 44.81 & 45.85 & 46.22 & $1.45 \%$ \\
\hline Indonesia & 50.15 & 49.80 & 51.36 & 51.52 & 51.35 & $0.60 \%$ \\
\hline \multicolumn{7}{|c|}{ Harvest Area (in 1000 ha) } \\
\hline Java & $6,358.00$ & $6,165.00$ & $6,186.00$ & $6,467.00$ & $6,000.00$ & $0.20 \%$ \\
\hline Outside Java & $6,895.00$ & $7,038.00$ & $7,260.00$ & $7,368.00$ & $7,393.00$ & $1.76 \%$ \\
\hline Indonesia & $13,253.00$ & $13,203.00$ & $13,446.00$ & $13,835.00$ & $13,793.00$ & $1.01 \%$ \\
\hline
\end{tabular}

Source: Ministry of Agriculture, Directorate General of Agricultural Infrastructure and Facilities, 2015 
When comparing Tables 1 and 2, it will be seen that fluctuations in the ups and downs of allocation of fertilizer subsidies and seeds are not rooted in national rice production which tends to increase steadily from year to year with a national average growth of 1,63 percent per year, even the lowest subsidy value in 2012 followed by a fairly high increase in national production (up around 3,3 million tons), with the highest level of productivity on the island of Java $(59,05 \mathrm{ku} / \mathrm{ha})$, where in the harvested area was relatively not much changed ( average growth of 0,2 percent per year), because the expansion of agricultural land on the island of Java is very limited and even tends to decrease due to the conversion of agricultural land to the industrial, trade and housing sectors, so the assumption of increased production is due to inappropriate land area factors, thus input subsidies look like they have no effect on rice yields during this period.

From the description, the policy of subsidizing rice fertilizers and seeds is the main concern of the allocation of government agricultural input subsidies that continue to increase from year to year, which is based on the central issue of food security issues, the problem of traditional agricultural patterns with the adoption of low agricultural technology, and sustainable agricultural development (Alghoziyah et al., 2016). In addition to being applied on the basis of consideration of these problems, it is also faced with the problem of economic inefficiency and government budget allocation, the occurrence of disparities in input prices (fertilizer and seeds) and the consequences of derivatives and the creation of false competitiveness due to the use of subsidized inputs (Zulkifli et al., 2014), so that the protection value of the policy needs to be analyzed, subsidy Input (fertilizer and seeds) on rice farming in Indonesia.

\section{ANALYTICAL METHOD}

This research uses quantitative methods with Policy Analysis Matrix (PAM) developed (Mobasser et al., 2012) used to analyze the effects of the policy of subsidizing agricultural inputs (fertilizer and seeds) on production so that the protection policy of subsidies is obtained, the effectiveness of the subsidy policy to inputs and outputs.

The operational limits and assumptions used in the Policy Analysis Matrix (PAM) are as follows (Rum, 2010; Kurniawan, 2011):

(1) Private or market prices are prices that farmers or producers actually receive and there are government policies in them

(2) The price of the shadow is the price in the perfect competitive market that represents the true cost of social balance. In tradable commodities, shadow prices are prices that occur in international markets

(3) Inputs are separated into tradable inputs and domestic resources or non-tradable inputs

(4) Tradable inputs are production inputs that can be traded internationally (such as chemical fertilizers and fuels)

(5) Non-tradable inputs or domestic factors are production inputs that are not traded on international markets (such as labor, land, capital)

(6) Physical output is rice agricultural production, in this case dry milled grain with a conversion to rice of 65 percent

(7) The private price of input is the actual price or market price of the production input paid by rice farmers

(8) The price of domestic factors is the price of non-tradable inputs paid by rice farmers based on the prices prevailing in the domestic market.

The assumption means that at the prices of commodity inputs and outputs analyzed there are disturbances in the form of regulations or restrictions from the government or failure, so that the prices that occur do not reflect the real or the value of scarcity. The output produced is traded goods (traded goods), which is a commodity whose price is determined by its import or export. Inputs used in the commodity system process consist of non-tradable domestic resources (tradable inputs) and tradable input factors. Non-tradable domestic factors are production inputs whose prices are determined by the domestic market. Non-tradable inputs are land, labor, capital and seeds. Besides that there are no 
negative and positive impacts on others who are not directly involved in the commodity system being analyzed (Siregar, 2016). In detail the resulting PAM table is presented in the table:

Table 3. Policy Analysis Matrix (PAM)

\begin{tabular}{|c|c|c|c|c|}
\hline \multirow{2}{*}{ Description } & \multirow{2}{*}{ Revenue } & \multicolumn{2}{|c|}{ Input } & \multirow{2}{*}{ Profit } \\
\hline & & Tradable & Non-tradable & \\
\hline Privat (Market) & A & $B$ & $C$ & D \\
\hline Social (Shadow) & $E$ & $F$ & G & $\mathrm{H}$ \\
\hline $\begin{array}{l}\text { Divergence } \\
\text { Effect }\end{array}$ & I & J & K & $\mathrm{L}$ \\
\hline
\end{tabular}

Description:

- $\quad$ Private Profit (Market Price) $(D)=A-(B+C)$

- Social Profit (Shadow Price) $(H)=E-(F+G)$

- $\quad$ Private Cost Ratio (PCR) $=\mathrm{C} /(\mathrm{A}-\mathrm{B})$

- Domestic Resource Cost Ratio (DRCR) $=G /(E F)$

- Nominal Protection Coefficient on Output $(N P C O)=A / E$

- Nominal Protection Coefficient on Input $(\mathrm{NPCl})=\mathrm{B} / \mathrm{F}$

- Effective Protection Coefficient $(E P C)=(A B) /(E-F)$

- Profitability Coefficient $(P C)=D / H$

\section{RESULT}

The results of the research are based on determining the private price (market) and social price (shadow), then the Policy Analysis Matrix (PAM) table can be prepared as follows:

Table 4. Policy Analysis Matrix (PAM)

\begin{tabular}{lcrrr}
\hline \multirow{2}{*}{ Description } & \multirow{2}{*}{ Revenue } & \multicolumn{1}{c}{ Input } & \multirow{2}{*}{ Profit } \\
\cline { 3 - 4 } & & \multicolumn{1}{c}{ Tradable } & \multicolumn{1}{c}{ Non-tradable } & \\
\hline Privat & 625291114968.00 & 747810482.37 & 74459928128.90 & 550083376356.73 \\
Social & 382781030463.94 & 1849103946.03 & 102995002868.47 & 277936923649.44 \\
Divergence & 242510084504.06 & -1101293463.66 & -28535074739.57 & 272146452707.29 \\
\hline
\end{tabular}

Source: Data Processed

Table 5. Results for the Policy Analysis Matrix Table Are as Follows

\begin{tabular}{lllr}
\hline Private Profit (D) & $\mathrm{A}-(\mathrm{B}+\mathrm{C})$ & $>0$ & 550083376356.73 \\
Social profit (H) & $\mathrm{E}-(\mathrm{F}+\mathrm{G})$ & $>0$ & 277936923649.44 \\
Profitability Coefficient (PC) & $\mathrm{D} / \mathrm{H}$ & $>0$ & 1.98 \\
Nominal Protection Coefficien on Input (NPCI) & $\mathrm{B} / \mathrm{F}$ & $>1$ & 0.40 \\
Nominal Protection Coefficient on Output (NPCO) & $\mathrm{A} / \mathrm{E}$ & $>1$ & 1.63 \\
Effective Protection Coefficient (EPC) & $(\mathrm{A}-\mathrm{B}) /(\mathrm{E}-\mathrm{F})$ & $>1$ & 1.64 \\
Private Cost Ratio (PCR) & $\mathrm{C} /(\mathrm{A}-\mathrm{B})$ & $<1$ & 0.12 \\
Domestik Resource Cost Ratio (DRCR) & $\mathrm{G} /(\mathrm{E}-\mathrm{F})$ & $<1$ & 0.27 \\
\hline
\end{tabular}

\section{DISCUSSION}

From the results of the analysis it is known that:

(1) Advantages of Financial / Private Profit (D) amounting to 550083376356,73 because D>0, it means that the commodity system gains profits at the price of the private price (market price), with a profit of around 5,5 million rupiah per hectare.

(2) Economic profit / social profit $(\mathrm{H})$ is 277936923649,44 because $\mathrm{H}>0$, it means that the commodity system benefits from costs at social prices (shadow Price), with a profit rate of around 2,8 million rupiah per hectare. 
(3) Profitability Coefficient (PC) is 1,98 because PC $>0$, it means that overall government policy provides incentives to know the profits to producers (farmers), about 98 percent of the social price or around 2,7 million rupiah higher than the social price or government subsidies that enter the rice farming sector in Indonesia are able to help increase farmers profits by 2,7 million rupiah per hectare from the unfortunate price. The divergence of large profits between private and social prices (98 percent), allows the government to reduce subsidy injections that enter the rice farming sector so that this sector will be able to enter the international market, but what remains is the question of whether large profit divergences (among others due to subsidies) are enjoyed by farmers or other parties outside the farmer, further studies or research are needed to solve the problem.

(4) Nominal Protection Coefficients on Input (NPCI) is 0,40 because the policy is protective against input if the NPCl value $>1$, it means that government policy is not protective against tradable inputs or subsidy input policies on rice farming provided by the government is not effective in maintaining the system is able to produce with the use of tradable inputs at a social price level (shadow), because the use of tradable inputs at market prices is 40 percent lower than their social prices, thus reducing or eliminating tradable input subsidies (tradable input prices will rise) may increase produce with the use of tradable inputs at the level of social prices (producers spend costs for tradable inputs that are equal or close to their social prices).

(5) Nominal Protection Coefficient on Output (NPCO) is 1,63 because the policy is protective against output if the value of NPCO $>1$, then it can mean that government policy is protective against output (the government's rice price control policy effectively controls domestic rice prices) or government policy able to maintain the price of agricultural production output of domestic rice at a rate of 63 percent higher than social prices (shadow) or producers (farmers) get 63 percent higher profit than social prices, but result in the output of agricultural production of rice plants in general unable to compete with international prices (cheaper), this is not a problem if the Value Protection Analysis 50 of Indonesia's rice crop production output is only intended to meet domestic food consumption needs but if production is also prepared to meet market needs world, a number of regulators are needed ation, realignment of the agricultural system, strengthening of agricultural technology and adequate institutional support as a whole until production output prices are able to approach world market prices and whether the magnitude of the benefits of government domestic rice price control policies is enjoyed by farmers or other related parties.

(6) Effective Protection Coefficient (EPC) is 1,64 because the policy is simultaneously protective if the EPC value> 1, it means that government policies are simultaneously protective (input and output side policies together) on production capability, or producers ( farmers) benefit from government policies on the input and output side together so that they are still able to continue to produce economically at private prices (markets), with a profit rate of 64 percent higher than the level of profit based on social prices, therefore the combination Input and output policies can be more effective in protecting rice farming systems in Indonesia, good coordination between institutions that are closely linked to rice farming systems is absolutely necessary to reduce inter-institutional policy distortions.

(7) Competitive advantage is measured by the Private Cost Ratio (PCR) of 0,12 because the system is competitive if $P C R<1$, meaning that the system of rice crop commodities has a competitive advantage on private prices (market) for domestic resource use, or at market prices the proportion of the use of domestic resource inputs (non-tradable) is around 88 percent greater than tradable inputs of around 12 percent, so that apart from natural factors and global climate change (global climate change) as a restriction, rice farming systems are still profitable to be cultivated and made as a buffer of national food security with improvements to the trading system and a set of regulations to maintain output prices at a reliable level for consumers and producers (farmers). Study or research is needed to find out the right trading system and the form of composition of government regulations that are able to maintain rice prices at a reliable level for consumers and producers (farmers) in the country. 
(8) Comparative advantage is measured by the value of Domestic Resource Cost Ratio (DRCR) that is equal to 0.27 because the system has a comparative advantage if $D R C R<1$, means that the system of rice crop commodities has a comparative advantage on social prices (shadow) on domestic resource use, or in social prices the proportion of the use of domestic resource inputs (non-tradable) is about 73 percent greater than tradable inputs of around 27 percent (rice farming systems supported by high domestic resource use or a very solid system in the use of domestic resources). The policy of restricting or prohibiting rice imports is still needed because the entry of imported rice will distort domestic rice prices, if the domestic price of rice falls to the level of its social price (shadow) because of the abundance of imported rice, the system of agricultural commodities of rice has no comparative (Zulkarnain and Kasymir, 2010), advantage. Studies or research on the impact of imported rice on domestic rice prices and rice farming systems are needed to maintain the accuracy of every government policy that is directly related to national rice problems.

\section{CONCLUSION}

The Value of Protection of Indonesian Rice Crop Policy based on Policy Analysis Matrix (PAM) explains that:

(1) The government policy is not protective against tradable input or input subsidy policy on rice farming provided by the government is not effective in maintaining rice farming systems to be able to produce with the use of tradable inputs at the level of social prices (shadow) because the market price of tradable inputs is 40 percent lower than social price.

(2) The government policy is protective against output (government rice price control policies effectively control domestic rice prices) or government policies are able to maintain the price of agricultural production output in domestic rice plants at a rate of 63 percent higher than social prices (shadow) or producers (farmers) get the profit is 63 percent higher than the social price (shadow), this condition causes the agricultural production output of rice plants in general cannot compete with international prices (cheaper), this is not a problem if the output of Indonesian rice crop production is only intended to meet the needs domestic food consumption but if the production is also prepared to meet the needs of the world market (export orientation) the resulting price level is not competitive.

(3) The government policies are simultaneously protective (input and output side policies together) on production capability, producers (farmers) benefit from government policies on the input and output side together so that they are still able to continue to produce economically at private prices (market), with a profit rate of 64 percent higher than the rate of profit on the basis of social prices.

Suggestions for further research are as follows:

(1) Reduction or elimination of tradable input subsidies (tradable input prices will rise) can increase production capability with the use of tradable inputs at the level of social prices (producers spend costs for tradable inputs that are the same or close to their social prices), in fact farmers are used to buying fertilizers and seeds at non-subsidized price level.

(2) If Indonesia's rice production is prepared to meet the needs of the world market (export orientation), a number of regulations are needed, realignment of the agricultural system, strengthening of agricultural technology and the support of an adequate institutional system as a whole so that production output prices are able to approach world market prices and whether the benefits due to policy controlling government domestic rice prices enjoyed by farmers or other related parties, more in-depth study or research is needed.

(3) The combination of input and output policies (synergistic) can be more effective and efficient to protect rice farming systems in Indonesia, good coordination between institutions that are closely related to rice farming systems in Indonesia is absolutely necessary to reduce interinstitutional policy distortions (reducing the risk of collisions policy at the implementation stage). 


\section{REFERENCES}

Kurniawan, A.Y. (2011). Analysis of Corn Farming Business Competitiveness in Dry Land in Tanah Laut Regency, South Kalimantan. Journal of Rural Agribusiness, 1(2), 83-99.

Mobasser, R.H., Rastegaripour, F., and Tavassoli, A. (2012). Study of effects of policy analysis matrix and relative advantage of rapeseed production (Case study: Sistan region). International Journal Of Agriculture And Crop Science, 4(19), 1421-1425.

Rum, M. (2010). Analysis of farmer business and government policy evaluation regarding large chili commodities in Malang Regency by using Policy Analysis Matrix (PAM). Journal Embryo, 7(2), 138-143.

Siregar, M. (2016). Analysis of soybean farming competitiveness in DAS Brantas. Journal of Agro Economic, 21(1), 50-71.

Susila, W.R. (2010). Fertilizer subsidy policy: Revisited. Journal of Agricultural Research and Development, 29(2), 43-49.

Zulkarnain, H.D. \& Kasymir, E. (2010). Comparative and competitive advantages in rice production in Central Lampung Regency, Lampung Province. Journal of Applied Agricultural Research, 10(3), 185-199.

Zulkifli, M., Harianto, and Nunung, N. (2014). Analysis of competitiveness of lowland rice farming in Indonesia: Case study of Bolaang Mongondow District, North Sulawesi Province. Academic Journals, 6(4), 85-90. 